\title{
Restructuring of Backrest and Drainage Provision System in the Campus Area
}

\author{
Ofik T. Purwadi, L. Afriani, and A. Zakaria
}

\begin{abstract}
The University of Lampung area, especially in the Faculty of ISIP, FEB, and FT is a densely packed student area. This area has undergone many land-use changes. The condition of the land as a green open space has changed its function to become an area for lecture buildings and offices. One of the impacts is an increase in direct surface runoff and a decrease in the quantity of water that seeps into the ground, this condition causes flooding during the rainy season. To facilitate the rehabilitation of the drainage system in the University of Lampung area, it is necessary to redesign the drainage system of the University of Lampung area. Rehabilitation of drainage channels is carried out to resolve flood inundation points that occur during the rainy season. Rainwater that is channeled through drainage channels is directed to natural or artificial reservoirs. The collected rainwater is used to recharge groundwater through natural infiltration methods. The analysis carried out in this study includes hydrological analysis and analysis of the existing drainage sections and the solutions are given. The hydrological analysis aims to calculate the planned discharge using the rational method. Modeling with the application used in this study aims to determine the capacity of the water level in the existing channel. Based on the results of the analysis, in the area, the Faculty of Engineering experienced runoff and inundation. This situation requires rehabilitation of the Lampung University area drainage system.
\end{abstract}

Index Terms - drainage, redesign, rehabilitation.

\section{INTRODUCTION}

Increasing rain intensity and shorter rainy seasons have resulted in increased flood intensity and frequency, increased erosion on the hillside, and downstream sedimentation/silting. Erosion has occurred in rivers, drains, water structures, reservoirs, etc. Thus, reducing the holding capacity of water reservoirs and infrastructure which causes flooding due to abundant water. Floods are recognized as a source of significant threat to human life [1]. In the global assessment of victims related to floods, one of them is Debris Flow. Flash floods can cause the highest number of deaths (the death toll divided by the number of people affected) [2]. In general, the drainage system can be defined as a series of water structures that function to reduce and/or remove excess water from an area or land, so that the land can be used optimally [3]. The purpose of this planning is to drain the momentary stagnant water that occurs during the rainy season and to drain dirty water from households. Excess water or momentary stagnant water occurs because the water balance in a certain area is disturbed. This is caused by the water that enters a certain area is greater than the water out.

Submitted on April 23, 2021.

Published on May 14, 2021.

Ofik T. Purwadi, Universitas Lampung, Indonesia.

(e-mail: mailto.ofik.taupik@eng.unila.ac.id)
The ideal data is data that is for and following what is needed. But in practice, incomplete records are often encountered. This can be caused by several things. This situation causes certain parts of the time-series data to contain missing records. The lost rain data can be estimated if there is a rain gauge (at least 2 stations) in the vicinity, which has complete data, or a measuring station where the data is lost, it is known that the annual average rainfall is found [4].

Linsley, Kohler, and Paulhus [5] suggested a method called the "Normal Ratio Method", the condition is that the difference in annual normal rainfall from post $\mathrm{X}$ where data is lost with the surrounding posts $>10 \%$ as follows.

$D_{x}=\frac{1}{n} \sum_{i=1}^{n} d_{i} \frac{A n_{x}}{A n_{i}}$

with:

$D_{x}=$ Maximum daily rainfall height data at station $\mathrm{x}$;

$n=$ The number of stations around $\mathrm{x}$ to find data on $\mathrm{x}$;

$d_{i}=$ Maximum daily rainfall height data at station I;

$A n_{x}=$ Average annual rainfall at station $\mathrm{x}$;

$A n_{i}=$ Average annual rainfall at stations around $\mathrm{x}$.

Consistency test means testing the correctness of the data. Consistent rain data means that the measured and calculated data is accurate and correctly aligned with the phenomenon when the rain occurs. Two ways to test the consistency of rain data are using double mass curve analysis and RAPS (Rescaled Adjusted Partical Sums). If the test results show that the rain data at a station is consistent, it means that in the area of influence of the system there has been no change in the environment and there has been no change in the method of measuring during the data recording and vice versa. In estimating the amount of lost data, it is necessary to pay attention to the pattern of rain distribution at the station concerned and the surrounding stations [6].

The rainfall used in the analysis is the calculated average maximum daily rainfall in one year. In this case, regional rain is required which is obtained from the average price of rainfall in several rainfall measurement posts around the area. There are 3 types of methods commonly used in calculating regional average rainfall: (1) algebraic mean, (2) Thiessen polygon and (3) Isohyet [7].

L. Afriani, Universitas Lampung, Indonesia.

(e-mail: afriani_1@eng.unila.ac.id)

A. Zakaria, Universitas Lampung, Indonesia.

(e-mail: ahmad.zakaria@eng.unila.ac.id). 


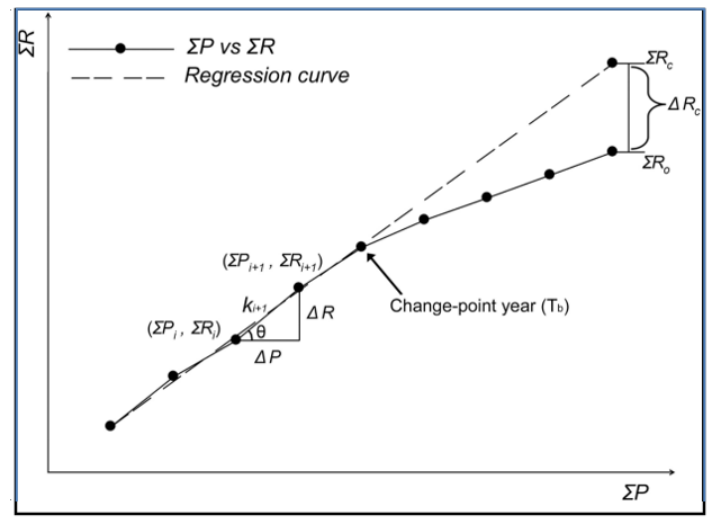

Fig. 1. Multiple Mass Curves (https://www.google.com, Fonlinelibrary.wiley.com)

Frequency analysis is used to determine the amount of rain or discharge with a certain return period. Amin [8] said that the stages of the analysis of the frequency of rain can be described as follows:

1. Prepare rain data that has been selected based on the best data selection method according to data availability.

2. Data sorted from small to large (or vice versa).

3. Calculate the amount of statistical data concerned (X, S, $\mathrm{Cv}, \mathrm{Cs}, \mathrm{Ck})$.

In frequency analysis the theoretical probability distribution suitable for existing data is determined based on statistical parameters such as mean value, standard deviation, asymmetry coefficient, coefficient of variation and coefficient of kurtosis. The statistical parameter formulas are as follows: Average value, standard deviation (S), skewness coefficient (Cs), coefficient of variation $(\mathrm{Cv})$, kurtosis coefficient $(\mathrm{Ck})$ and concentration time [9]. According to Edisono [10], concentration time is the time required to flow water from the farthest point in the flow to a specified control point in a flow. In principle, concentration time is divided into:

1. Inlet time (to), which is the time required for water to flow on the ground to the drainage channel.

2. Conduit time (td), which is the time required for water to flow along the channel to a specified point.

Rain intensity is the height or depth of rainwater per unit time. The general characteristic of rain is that the shorter the rain lasts, the intensity tends to be higher and the greater the return period, the higher the intensity. Planned discharge is the discharge time to return which is used to determine the flood discharge in a certain period. There are several methods in drainage planning to obtain a planned discharge, namely Weduwen, Haspers and Rational. For the rational itself, the boundary condition is DAS $<60 \mathrm{~km}^{2}$, for the Weduwen method the watershed boundary condition is $<100 \mathrm{~km}^{2}$ and Haspers has a watershed boundary condition $<300 \mathrm{Km}^{2}$. Because the University of Lampung watershed is around 60 $\mathrm{Ha}-70 \mathrm{Ha}$, these 3 methods are included in the boundary requirements for use.

In the Rational Method, the equation used is as follows:

$Q r=0,278 \times C \times I \times A$

where:

$Q r=$ Discharge time plan return $\left(\mathrm{m}^{3} / \mathrm{sec}\right)$;

$C=$ Flow Coefficient;
$I=$ Specific Rainfall Intensity ( $\mathrm{mm} /$ hour);

$A=$ Area of Watershed $\left(\mathrm{km}^{2}\right)$.

The speed in a channel usually varies greatly from one point to another. This is due to the presence of shear stress at the base of the channel, the channel walls and the presence of a free surface. Flow velocity has three directional components according to Cartesian coordinates. However, the vertical and lateral components are usually small and negligible. Thus, only the flow velocity in the direction of flow is considered. This velocity component varies with the depth of the water surface. The minimum speed allowed is the smallest speed that does not cause precipitation and does not stimulate the growth of aquatic plants and algae. In general, speeds of 0.60$0.90 \mathrm{~m} / \mathrm{s}$ can be used with safe if the percentage of sludge in the water is quite small. The speed of $0.75 \mathrm{~m} / \mathrm{s}$ can prevent the growth of moss. The determination of the speed of water flow in the planned channel is based on the minimum speed allowed so that the channel construction remains safe. The Manning equation is as follows:

$V=\frac{1}{n} \times R \frac{2}{3} \times S \frac{1}{2}$

where:

$V=$ Flow velocity $(\mathrm{m} / \mathrm{sec})$;

$n=$ Manning roughness coefficient;

$R=$ hydraulic radius;

$S=$ slope of the channel.

Manning $\mathrm{n}$ price depends on the roughness of the side and bottom of the channel. Basically, infiltration wells are in the form of dug holes made in yards, plantations, and rainwater rice fields. The dimensions of the infiltration well are determined by several factors, namely: rain characteristics, cover surface area, and soil permeability coefficient. To determine the dimensions of the infiltration wells based on the factors described, the developed calculation method, namely the Sunjoto method [11] is used. HEC-RAS is a bundled piece of software, designed for interactive use in environments. This system consists of a Graphical User Interface (GUI), hydraulic analysis components, data storage and management capabilities, graphics, and reporting facilities [11].

\section{METHODOLOGY}

This study was carried out in a drainage network located at the University of Lampung around the Faculty of Engineering, Faculty of Economics and Business, Faculty of Social and Political Sciences, Faculty of Law.

Primary data is in the form of existing data, in the form of drainage cross-sectional size, flow direction, material data, topographic measurements, flood points. Secondary data contains topographic data in the form of contour data, Unila master plan, rainfall data, and Masterplan map.

Collecting survey data, analyzing the pattern of the existing drainage flow direction, planning the flow pattern, calculating the discharge plan, calculating the cross-sectional discharge of the existing channel, checking the discharge of the existing channel (Qs) with the planned discharge (Qr), describing the new cross-sectional design and the budget design. 


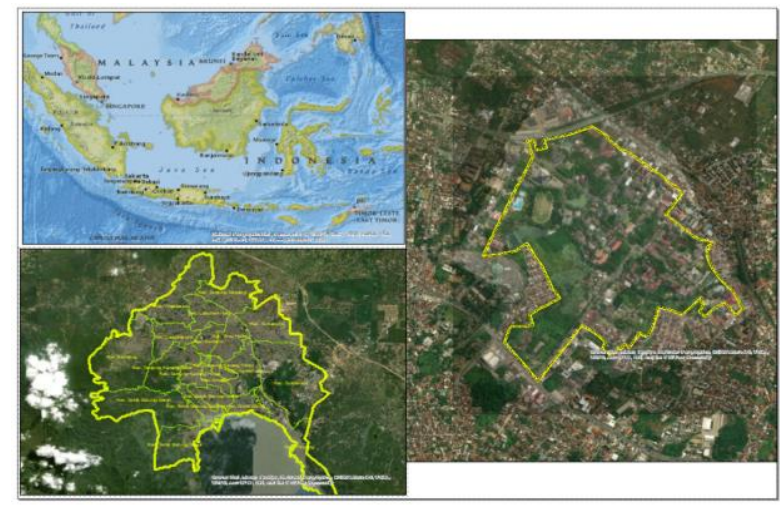

Fig. 2. Research Site.

Analyze and calibrate water level elevation data using HEC-RAS. After performing the analysis using the HECRAS program, the water level elevation was obtained in the output HEC-RAS file. However, the results of these outputs are not necessarily accurate or certain with these results. Therefore, a calibration step is needed by comparing the data in the field with the HEC-RAS simulation. This is done to prove the Manning number (n) obtained from the calculation is appropriate or not.

\section{RESUlTS}

Hydrological analysis in drainage planning is carried out to determine the magnitude of the planned flood discharge which affects drainage safety. The calculation of the planned flood discharge in this study was carried out using daily rainfall data from rain stations around the drainage plan location due to the unavailability of discharge data. The analysis data was taken from the Polynella rain station data.

The calculation of the planned discharge is carried out using the Rational method as a reference for the planned discharge value used on the grounds that the Rational method has been recommended in the Minister of Public Works No. $12 / 2014$ and the rational discharge value is suitable for DAS $<100 \mathrm{Ha}$, then the selection of rational discharge is used in designing the cross-section drainage and checking channel capacity because it is quite ideal and economical.

$$
\mathrm{Q}=0.2778 \times \mathrm{C} \times \mathrm{I} \times \mathrm{A} \mathrm{C}=0.6478
$$

For calculations made a table as in Table 1 Example of calculation taken is No.1. With the drainage code D3-D1. In the 5-year return period with $\mathrm{I}=1,361,154 \mathrm{~mm} / \mathrm{h}$ with a drainage area of $0.0039 \mathrm{~km}^{2}$ with a combined flow coefficient of 0.6478 .

$Q=0.278 \times 0.6478 \times 1.361 .154 \times 0.0039 \mathrm{~km}^{2}=0.0973 \mathrm{~m}^{3} / \mathrm{s}$

From the results of these calculations, it can be seen in Table I.

TABLE I: Discharge CALCULATION RATIONAL METHOD DESIGN INTENSITY TIME CONCENTRATION

\begin{tabular}{cccccc}
\hline \hline No & Drainage Code & $\mathrm{C}$ & $\mathrm{I}(\mathrm{mm} / \mathrm{jam})$ & $\mathrm{A}\left(\mathrm{km}^{2}\right)$ & $\mathrm{Q}\left(\mathrm{m}^{3} / \mathrm{s}\right)$ \\
\hline 1 & D3 - D1 & 0,6478 & $1,361,154$ & 0,0039 & 0,0973 \\
2 & D3 - D14 & 0,6478 & 910,001 & 0,0037 & 0,0619 \\
3 & D5 - D13 & 0,6478 & 982,581 & 0,0014 & 0,0259 \\
4 & D5B - D13B & 0,6478 & 711,276 & 0,0063 & 0,0817 \\
5 & D36 - D25 & 0,6478 & 73,856 & 0,0008 & 0,0109 \\
6 & D36-D37 & 0,6478 & $1,323,889$ & 0,0014 & 0,0340 \\
7 & D37 - D29 & 0,6478 & 564,049 & 0,0028 & 0,0284 \\
8 & D24 - D21 & 0,6478 & $1,496,360$ & 0,0018 & 0,0485 \\
9 & D24-D29 & 0,6478 & 790,943 & 0,0083 & 0,1192 \\
10 & D14 - D18 & 0,6478 & $1,124,052$ & 0,0047 & 0,0958 \\
11 & D12-D14 & 0,6478 & $1,078,009$ & 0,0034 & 0,0670 \\
12 & D18-D21 & 0,6478 & 903,518 & 0,0027 & 0,0109 \\
13 & D25 - D18 & 0,6478 & $1,775,885$ & 0,0027 & 0,0879 \\
14 & D37 - D25 & 0,6478 & 324,887 & 0,0024 & 0,0141 \\
15 & D21 - D29 & 0,6478 & 798,655 & 0,0030 & 0,0439 \\
\hline \hline
\end{tabular}

TABLE II: CALCULATION OF DiSCHARGE DESIGN METHODS RATIONAL INTENSITY DURATION OF RAIN IN BANDAR LAMPUNG

\begin{tabular}{cccccc}
\hline \hline No & Drainage Code & $\mathrm{C}$ & $\mathrm{I}(\mathrm{mm} / \mathrm{jam})$ & $\mathrm{A}\left(\mathrm{km}^{2}\right)$ & $\mathrm{Q}\left(\mathrm{m}^{3} / \mathrm{s}\right)$ \\
\hline 1 & D3 - D1 & 0,6478 & 350,562 & 0,0039 & 0,0251 \\
2 & D3 - D14 & 0,6478 & 350,562 & 0,0037 & 0,0238 \\
3 & D5 - D13 & 0,6478 & 350,562 & 0,0014 & 0,0092 \\
4 & D5B - D13B & 0,6478 & 350,562 & 0,0063 & 0,0403 \\
5 & D36-D25 & 0,6478 & 350,562 & 0,0008 & 0,0052 \\
6 & D36-D37 & 0,6478 & 350,562 & 0,0014 & 0,0090 \\
7 & D37-D29 & 0,6478 & 350,562 & 0,0028 & 0,0177 \\
8 & D24-D21 & 0,6478 & 350,562 & 0,0018 & 0,0114 \\
9 & D24-D29 & 0,6478 & 350,562 & 0,0083 & 0,0528 \\
10 & D14-D18 & 0,6478 & 350,562 & 0,0047 & 0,0299 \\
11 & D12-D14 & 0,6478 & 350,562 & 0,0034 & 0,0218 \\
12 & D18-D21 & 0,6478 & 350,562 & 0,0027 & 0,0109 \\
13 & D25 - D18 & 0,6478 & 350,562 & 0,0027 & 0,0173 \\
14 & D37-D25 & 0,6478 & 350,562 & 0,0024 & 0,0152 \\
15 & D21-D29 & 0,6478 & 350,562 & 0,0030 & 0,0193 \\
\hline \hline
\end{tabular}


Analysis of the cross-sectional capacity of the channel and the flow direction pattern of the water table was carried out using a program to analyze the cross-sections. There are many existing programs such as the HEC-RAS 4.1.0 program. From this program, we can analyze existing drainage sections that are no longer able to accommodate the existing flood discharge so that runoff occurs in the drainage and there is no drainage channel in certain areas so that drainage cross-sectional planning is required in some of these areas. Runoff occurs at DN 13 and DN 12 sections with a water level of $40 \mathrm{~cm}$ and $10 \mathrm{~cm}$ overflow for $10 \mathrm{~m}$. The new drainage section plans are at the points DN13 to DN12 for 48 $\mathrm{m}$ and DN 15 to DN 16 for $22 \mathrm{~m}$.

From Tables 2 and 3, it is obtained the planned discharge for the 5-year return period from each drainage section using the rational method. Fig. 3 is a case where the study environment, unila there was a flood 1 year ago, before drainage was revitalized.

From the results of the analysis using the program, there is an existing drainage section that is not able to accommodate the existing flood discharge so that there is runoff in the drainage and there is no drainage channel in certain areas, so it is necessary to plan drainage sections in some of these areas. Runoff occurs in sections D12 and D13 with a water level of $33 \mathrm{~cm}$ and $22 \mathrm{~cm}$ overflow over $55 \mathrm{~m}$. The new drainage section plans are at points D13 to D12 along $100 \mathrm{~m}$ and D15 to D16 along $100 \mathrm{~m}$. Table I is the evaluation result of the cross section which determines whether the flow in the study location has overflowed or not.

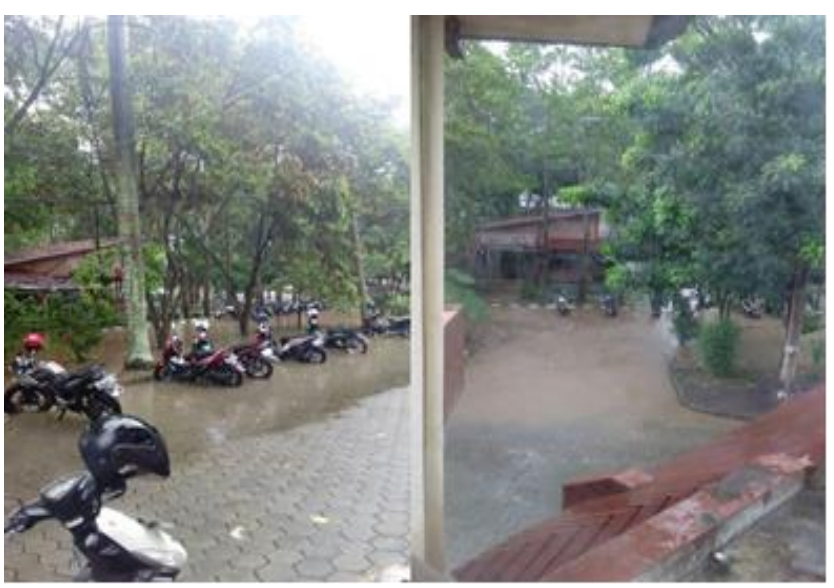

Fig. 3. Flood Points D13, D12, D15 and D16.

\begin{tabular}{|c|c|c|c|c|c|c|c|c|c|}
\hline No & $\begin{array}{c}\text { Drainage } \\
\text { Code }\end{array}$ & $\begin{array}{l}\text { High } \\
\text { Drains }\end{array}$ & $\begin{array}{l}\text { Water } \\
\text { Level }\end{array}$ & Description & No & $\begin{array}{c}\text { Drainage } \\
\text { Code }\end{array}$ & $\begin{array}{c}\text { High } \\
\text { Drains }\end{array}$ & $\begin{array}{l}\text { Water } \\
\text { Level }\end{array}$ & Description \\
\hline 1 & D1 & 0,60 & 0,24 & not overflowed & 21 & D21 & 1,05 & 0,24 & not overflowed \\
\hline 2 & D2 & 0,30 & 0,30 & not overflowed & 22 & $\mathrm{D} 22$ & 1,15 & 0,15 & not overflowed \\
\hline 3 & D3 & 0,57 & 0,12 & not overflowed & 23 & D23 & 0,75 & 0,15 & not overflowed \\
\hline 4 & D4 & 0,58 & 0,12 & not overflowed & 24 & D24 & 0,72 & 0,10 & not overflowed \\
\hline 5 & D5 & 0,60 & 0,24 & not overflowed & 25 & $\mathrm{D} 25$ & 0,26 & 0,10 & not overflowed \\
\hline 6 & D6 & 0,42 & 0,18 & not overflowed & 26 & D26 & 0,28 & 0,25 & not overflowed \\
\hline 8 & D8 & 0,40 & 0,35 & not overflowed & 28 & D28 & 0,62 & 0,20 & not overflowed \\
\hline 9 & D9 & 0,45 & 0,30 & not overflowed & 29 & D29 & 2,40 & 0,24 & not overflowed \\
\hline 10 & D10 & 0,48 & 0,12 & not overflowed & 30 & D30 & 0,44 & 0,15 & not overflowed \\
\hline 11 & D11 & 0,32 & 0,16 & not overflowed & 31 & D31 & 0,40 & 0,20 & not overflowed \\
\hline 12 & D12 & 0,27 & 0,60 & overflowed & 32 & D32 & 0,40 & 0,20 & not overflowed \\
\hline 13 & D13 & 0,27 & 0,49 & overflowed & 33 & D33 & 0,42 & 0,23 & not overflowed \\
\hline 14 & D14 & 0,40 & 0,24 & not overflowed & 34 & D34 & 0,37 & 0,15 & not overflowed \\
\hline 15 & D15 & 0,27 & 0,49 & overflowed & 35 & D35 & 0,40 & 0,27 & not overflowed \\
\hline 17 & D17 & 0,49 & 0,24 & not overflowed & 37 & D37 & 0,29 & 0,21 & not overflowed \\
\hline 18 & D18 & 0,26 & 0,12 & not overflowed & 38 & D38 & 0,52 & 0,10 & not overflowed \\
\hline 19 & D19 & 1,16 & 0,15 & not overflowed & 39 & D39 & 0,60 & 0,15 & not overflowed \\
\hline 20 & D20 & 1,10 & 0,25 & not overflowed & 40 & D40 & 0,65 & 0,11 & not overflowed \\
\hline
\end{tabular}

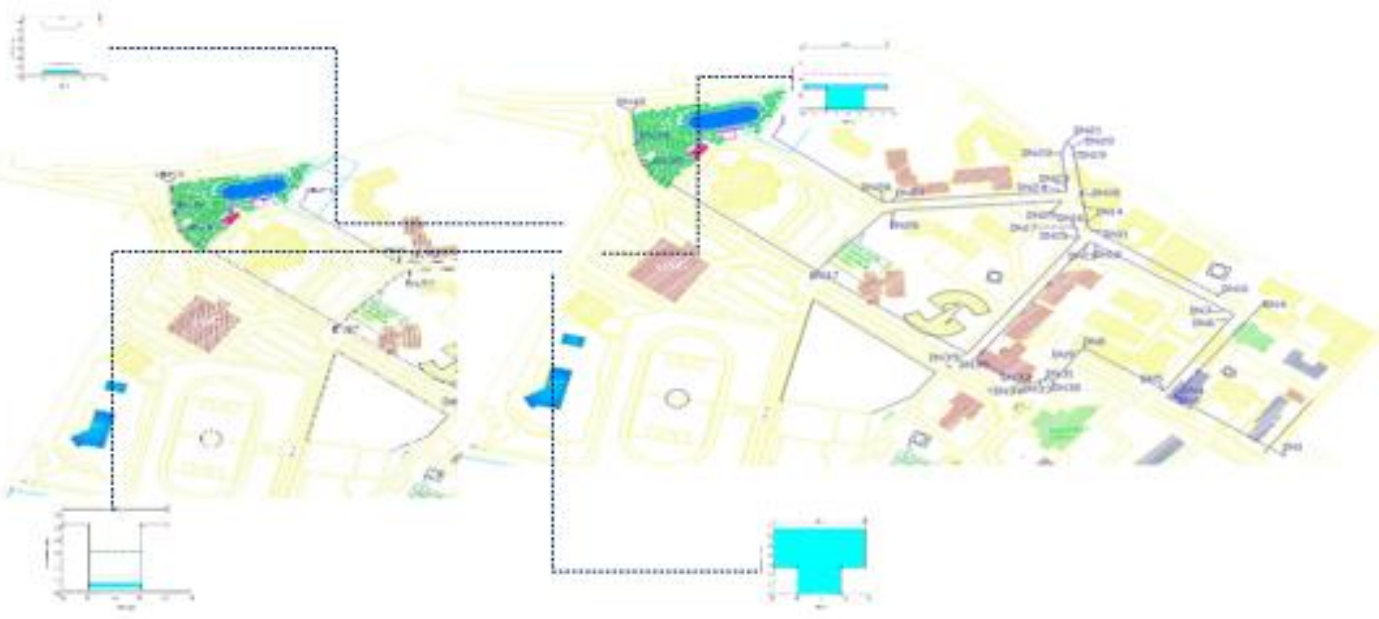

Fig. 4. Water Face Profile at Cross Section DN 12 and DN 13, DN 15 and DN 16. 


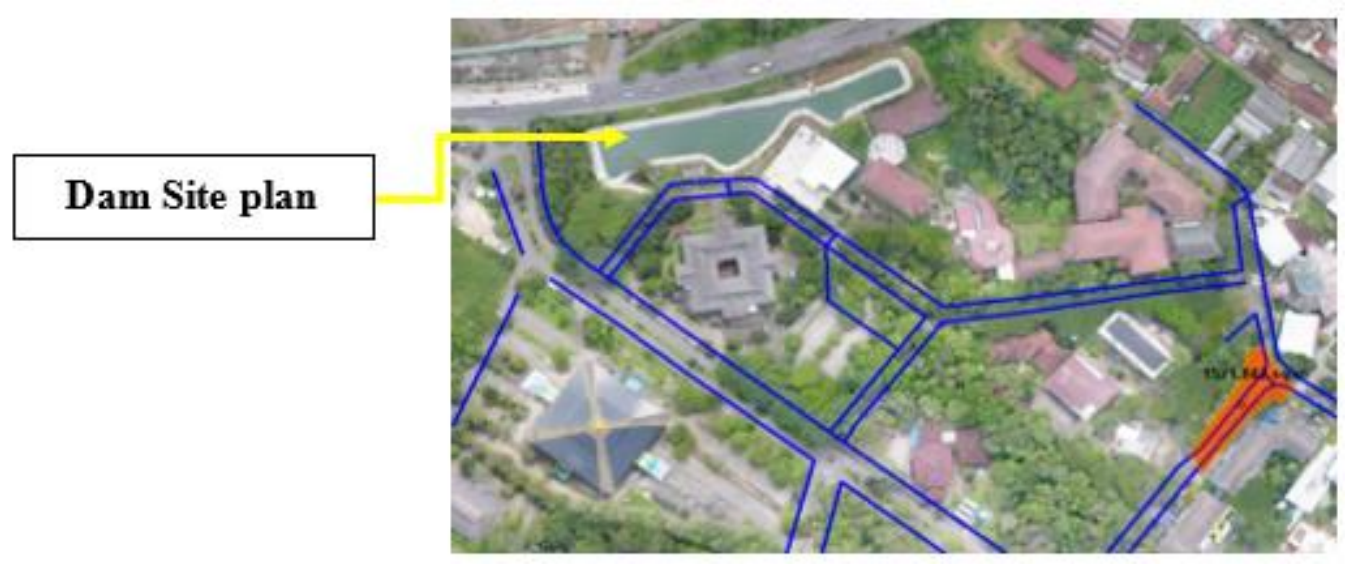

Fig. 5. Drainage System and Embung Construction Location Plan.

\section{CONCLUSION}

Based on the analysis that has been done, it is found that the flood point occurs in the DN13 and DN12 sections with a water level of $40 \mathrm{~cm}$ and $10 \mathrm{~cm}$ of overtopping with long 10 $\mathrm{m}$ which is located in front of the Unila Engineering Canteen. There is also a plan for a new drainage section located at DN13 to DN12 and DN15 to DN16 in length $48 \mathrm{~m}$ and $22 \mathrm{~m}$. The construction of infiltration wells can help the drainage performance of the Faculty of Economics to the Faculty of Engineering, especially to deal with high volume, short duration, and large return times of rain. Flood runoff that can be absorbed by infiltration wells is $32.70 \%$ of the total runoff. Rehabilitation of the drainage system at the University of Lampung area is carried out by normalizing the drainage channels, increasing the depth of the drainage channels, changing the direction of the drainage flow, installing garbage retaining lattices, periodically cleaning the channels, and harvesting rainwater centrally by means of making a reservoir, retention pond or reservoir. For the problem of flooding in the study area, it is advisable to change the size of the existing section at points DN12, DN13, DN15 and DN16. In the results of the analysis in the research area, it is suggested to design infiltration wells with 4 types, 0.5 -meter, 1-meter, 1.5-meter and 2-meter depth with diameter size $80 \mathrm{~cm}$.

\section{RECOMMENDATION}

It is recommended to construct infiltration wells to reduce ground water level drawdown that causes settlement during times of high intensity of rain with short duration, to prevent the rate of soil erosion due to surface runoff and groundwater conservation. To make off site rainwater harvesting with the system centralized, namely embung (conservation basin retention).

\section{REFERENCES}

[1] Bevere, L., et al. Natural catastrophes and man-made disaster in 2014 convectiveand winter storms generate most losses. Zurich: Swiss Re. 2015.

[2] Braud, I. Flash Floods, Hydro-geomorphic Response and Risk Management. Lyon: Elsevier. 2016.

[3] Suripin. Sistem Drainase Perkotaan yang Berkelanjutan. Andi Offset. Yogyakarta. 2004.
[4] Limantara, Lily Montarcih. Hidrologi Praktis. Bandung: Lubuk Agung, 2010.

[5] Linsley JR, Ray K.; Kohler, Max Adam; Paulhus, Joseph LH. Hydrology for engineers. Ann Arbor: McGraw-Hill. 1975.

[6] Dewi, V.A.K. Tugas Besar Hidrologi Dasar. Malang: Universitas Brawijaya. 2012

[7] Haryoko, L.O. Evaluasi dan Rencana Pengembangan Sistem Drainase di Kecamatan Tanjung Karang Pusat. Lampung: Universitas Malahayati. 2013.

[8] Amin, M. B. M. Baitullah Al Amin Blog. Retrieved Oktober 30, 2016 (2010, Juni 6). from http://baitullah.unsri.ac.id/2010/06/analisisfrekuensi/.

[9] Florince. Studi Kolam Retensi sebagai Upaya Pengendalian Banjir Sungai Way Simpur Kelurahan Palapa Kecamatan Tanjung Karang Pusat. Lampung: Universitas Lampung. 2015.

[10] Edisono, et al. Drainase Perkotaan. Jakarta: Gunadarma. (1997).

[11] Sunjoto, S. Optimasi Sumur Resapan Air Hujan Sebagai Salah Satu Usaha Pencegahan Intrusi Air Laut. Yogyakarta. 1988.

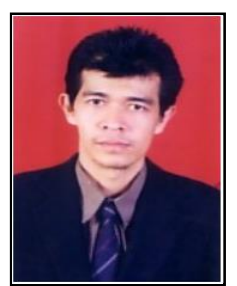

Ofik T. Purwadi was born in Majalengka on July 24,1970 . He studied undergraduate education at the University of Lampung, Lampung, Indonesia and obtained a Bachelor of Engineering (ST) in civil engineering on December 24, 1997. Then continued his studies at the Bandung Technology Institute, West Java, Indonesia in the field of civil engineering with a master's degree in engineering (MT) which was completed on October 6, 2001.

$\mathrm{He}$ currently works as a lecturer in the civil engineering study program at the University of Lampung, Lampung, Indonesia.

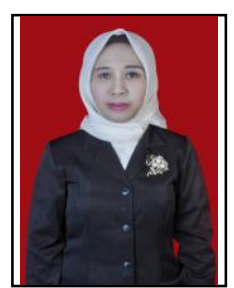

L. Afriani was born in Palembang on 10 May 1965 She started her education at the diploma level three (D3) majoring in civil engineering at the University of Lampung, Lampung, Indonesia and obtained an A.Md. in 1988. In 1991 he obtained a bachelor's degree in engineering in the field of civil engineering at the Sepuluh November Institute of Technology, Surabaya, Indonesia with a S.T. For the master's level he went to Universite de Caen, France and obtained the title Dr. D.E.A. obtained in 1999 and 2004.

$\mathrm{He}$ is currently working as a lecturer in the civil engineering study program at the University of Lampung, Lampung, Indonesia. apart from being a lecturer, he has served as Deputy Dean I of the Faculty of Engineering, University of Lampung, Dean of the Faculty of Engineering, University of Lampung, in charge of Vice Chancellor IV for collaboration at the University of Lampung, Head of the Laboratory of Soil Mechanics, Faculty of Engineering, University of Lampung, and now he serves as Chair of the Research Institute and Community service. 


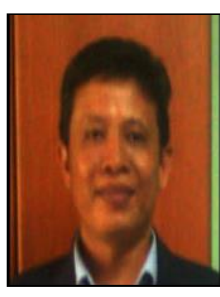

A. Zakaria Ahmad Zakaria was born in Palembang May 14, 1967. First Degree (Ir) in Civil Engineering, University of Sriwijaya, Palembang, Indonesia in 1992. Second Degree, Masters in Civil Engineering (M.T) in Water Resources Bandung Institute of Technology. Bandung, Indonesia in 1998. Third Degree, Doctor of Philosophy (Ph.D) in Coastal and Marine Studies at Curtin University of Technology, Perth, Australia in 2003.

$\mathrm{He}$ is currently working as a lecturer in the civil engineering study program at the University of Lampung, Lampung, Indonesia. 